\title{
NUEVAS NOTICIAS SOBRE UN TALLER DE ARTISTAS DE LA NOBLEZA INDIGENA
}

\section{Gustavo Curiel}

\begin{abstract}
"Todo lo cual se obliga el dicho Salvador Ocampo a hacer como tal maestro, de maderas secas de cedro y ayacaguite, poniendo todos los materiales, oficiales y herra. mientas que fueren necesarias, dorado de oro limpio, menos la pintura, que ésta se obliga el dicho Nicolás Rodríguez a hacerla, dándole dicho maestro escultor los tableros para ella, de planchas de cedro viejo, embarrotadas a cola de Milán, ixtiados por detrás, enlenzados, aparejados y empinados por la cara".
\end{abstract}

(Retablo Mayor de los Santos Reyes, Meztitlán).

Cierto es que de pocos años a la fecha han comenzado a aparecer, fruto de la paciente labor de investigación en los archivos documentales, nombres y referencias concretas a la obra de aquellos artistas que trabajaron en la ejecución de los suntuosos retablos dorados destinados a ornamentar los templos y los conventos de la Nueva España.' Lo anterior ha permitido, por ejemplo, identificar a nuevos pintores y trabajadores de la madera, activos desde por lo menos los últimos treinta años del siglo XVII hasta la primera mitad del XVIII. A nombres como Xuárez, Rojas, Roa, Balbás, o Ureña se han agregado los de Nava, Ramírez, Maldonado-Montero, de Pinos y otros, que por desviarse de los objetivos principales de este pequeño trabajo no vale la penâ mencionar. ${ }^{2}$ Cabe advertir, sin em-

1 La bibliografía al respecto ha crecido en los uiltimos años. Compárense los nombres de artistas ahora conocidos con los que aparecen registrados en la nómina de los siguien. tes estudios: José Moreno Villa, La escultura colonial mexicana (1942), obra que por desgracia no fue puesta al día cuando fue reeditada en 1986 en el Fondo de Cultura Económica; Manuel Toussaint, Arte colonial mexicano - (1948); Abelardo Carrillo y-Gatiel, Autógrafos de pintores coloniales (1972).

2 Tanto Efraín Castro Morales como Guillermo Tovar de Teresa se han ocupado de estudiar a estos artistas. Cfr. también los Catálagos de documentos de orte del Instituto de Investigaciones Estéticas de la UNAM, en los que se registran otros datos importantes al respecto. 
bargo, que aún es mucho lo que falta por investigar e interpretar en este rico y por largos años ignorado campo del arte novohispano. Por desgracia todavía es poco lo que se sabe acerca del funcionamiento de los gremios y de las cofradías, así como de las interrelaciones que estas agrupaciones religioso-laborales mantuvieron con los artistas. ${ }^{3}$ Asimismo, se puede decir que es escasa la bibliografía que informa sobre los mecanismos de transmisión de formas y aquella que refiere la dinámica que éstas adoptaron en los retablos. ${ }^{4}$ Una de las tareas que apenas inicia el historiador del arte es la de atribuir algunos de estos ejemplos a artistas concretos, teniendo como base para tal acción tanto la información de los testimonios notariales como el análisis formal e iconográfico de los retablos.

Hace ya tiempo Heinrich Berlín se quejaba, no sin razón, en un valioso estudio del lamentable estado en que se encontraba la investigación de la escultura y los retablos. Este autor consignó en 1948 los siguientes juicios que conviene ahora traer a cuenta:

The historian of art in colonial Mexico can find his way fairly well in the field of painting, since the signatures of painters appear on the pictures; in the field of architecture a growing body of published documents makes it possible to become familiar with the personalities of the architecs. In regard to sculpture, however, there is practically no information available. We know hardly the names of any of the men who carved the church fronts and furniture, or who made the hundreds of altarpieces that we admire in Mexican churches... It is imperative to push forward the investigation of colonial sculpture, not only in terms of general concepts, by defining the character of individual sculptors, their development, their tastes and capacities, and the influences... At present there are actually very few sculptors known even by name. ${ }^{5}$

Si bien la anterior perspectiva ha cambiado fundamentalmente y en la actualidad se cuenta con un mayor número de nombres de artistas y

${ }^{3}$ Cfr. Rogelio Ruíz Gomar, "El gremio y la cofradía de pintores en la Nueva España" en Juan Correa. Su vida y su obra. Cuerpo de documentos. Tomo III, primera y segunda partes, 1985. Inédito.

${ }^{4}$ Destacan algunos estudios que aclaran el comportamiento de las formas en los retablos. Véase: Jorge Alberto Manrique, "El transplante de las formas artísticas españolas a México" en Actas del Tercer Congreso Internacional de Hispanistas, México, El Colegio de México, 1969. Asimismo, el número 106, "Retablos mexicanos", de Artes de México, de Francisco de la Maza, El cburrigueresco en la ciudad de México, México, Fondo de Cultura Económica, 1969 (Presencia de México, No. 9) y de Joseph Baird, Los retablos del siglo XVIII en el sur de España, Portugal y México, México, Instituto de Investigaciones Estéticas, UNAM, 1987 (Estudios de Arte y Estética, No. 24).

${ }^{5}$ Heintich Berlín, "Salvador de Ocampo, A Mexican Sculptor", en The Americas, Har" vard, Academy of Franciscan Histoty, 1948, Vol IV, abril, No. 4, pp. 415-416. 
de referencias documentales a obras concretas, resulta indispensable que el historiador del artc aborde in urgente y para nada fácil tarea de "armar", como si se tratara de volver a unir con coherencia las piezas de un rompecabezas, los curricula artísticos de los trabajadores de la escultura y del ensamblaje. Partiendo para tal fin tanto de la información contenida en fuentes escritas, sea o no de primera mano, como de la que proviene del riguroso análisis formal de los retablos y fragmentos de éstos que tuvieron la fortuna de llegar al presente siglo. Sólo en esta forma será posible conocer aquellas soluciones formales que dieron fama, carácter y solidez a los artistas, al tiempo que se podrán comprender en forma más realista las dimensiones y los alcances que llegaron a tener ciertos talleres novohispanos. ${ }^{6}$

No se debe perder de vista que hasta hace relativamente poco tiempo se ignoraba incluso la existencia de familias enteras de artistas que participaron en la ejecución de multitud de retablos; con el paso de los años las dinastías han vuelto a ocupar sus primitivos lugarẹs y es posible reconocer, en debida forma, la importancia que tuvieron los artistas siglos atrás. Ilustran el caso los Maldonado, los Ramírez y los Nadal, por mencionar tan sólo tres apellidos que han salido recientemente a la luz, todos de primerísima línea. ${ }^{7}$ Nombres, obras y talleres toman de nueva cuenta su sitio. Alrededor de las figuras más relevantes han comenzado a aparecer otros personajes ligados a los artistas, casi siempre por fuertes lazos económicos. Yernos, suegros y otros familiares no consanguíneos, cabe aclarar, respaldaron frecuentemente con sus bienes las operaciones de los talleres familiares de escultura y ensamblaje, al obligarse, junto con los maestros, a conseguir el feliz término de lo pactado en las Condiciones de los Conciertos de Obligación de Obra ${ }^{8}$ En la actualidad los artistas aparecen en los testimonios notariales relacionados unos con otros, formando

${ }^{6}$ No hay que perder de vista que muchos de los tetablos han artibado al siglo XX mutilados, rasurados de decoración barroca y con cambios en el programa iconográfico. Los anteriores factores deben ser tomados en cuenta al estudiar estas obras.

${ }^{7}$ Cfr. Efraín Castro Morales, "Juan Montero, ensamblador y arquitecto novohispano del siglo XVII" en Boletin de Montumentos Históricos, México, Dirección de Monumentos Históricos, INAH, 1981, No 6, pp. 5-26. Del mismo autor: "Los Ramírez, una familia de artistas novohispanos del siglo XVII" en Boletín de Monumentos Históricos, México, Dirección de Monumentos Históticos, INAH, 1982, No. 8, pp. 5-36. Así como, Guillermo Tovar de Teresa, "Consideraciones sobre retablos, gremios y artífices de la Nueva España en los siglos XVII y XVIII" en Historia Mexicana, Nos. 132-133, México, El Colegio de México, 1986, pp. 5-40.

${ }^{8}$ Ilustra este caso la familia del maestro mayor de arquitectura Cristóbal de Medina Vargas. Cfr. Gustavo Curiel, "Cristóbal de Medina Vargas Machuca y las reparaciones de la casa del capitán de Avendaño (1672)" en Anales 58 del Instituto de Investigaciones Estéticas, UNAM, 1987, pp. 187-195. 
grupos más o menos distinguibles, concertando obras y mezclándose con otros talleres, de lo que resulta un panorama más amplio de las labores del taller familiar y de la bien redituada actividad artística que fue la retablística novohispana.?

Pasando a otra cuestión, no está por demás recordar que la construcción y adorno de los retablos fue una empresa determinada en gran medida por un marcado carácter comunitario. Hay que decir que en ella participaron gran número de trabajadores de la madera de muy diversas clases. Variedad de pintores, doradores, escultores y ensambladores fueron los responsables directos de la ejecución material. Sin embargo, al analizar los retablos frecuentemente se pierde de vista la gran cantidad de individuos que participaron en forma indirecta en la consecución de tales empresas artísticas. Destacan en este rubro, en un lugar preponderante, los patronos o encargantes de las obras, ya que fueron ellos quienes determinaron en más de un aspecto la forma y decoración que deberían tener los retablos. Los veedores y otras autoridades observaron el cumplimiento de "las calidades" y propiedad de los mensajes, que a veces quedaban estipulados en las Condiciones de obra. Y finalmente - pero no por ello menos importantes - los fiadores y testigos de acto, que junto con los notarios dieron cuenta legal y respaldo económico a lo asentado en los protocolos notariales. Todos, como se ha visto, relacionados de una u otra manera con la obra artística y con su realización.

Una vez asentado lo anterior, hay que añadir que la investigación documental es vía indispensable para acceder al conocimiento de otra serie de problemáticas artísticas en intima relación con la construcción de los retablos. Destacan, por ejemplo: gusto artístico, mecenazgo, clientela, reutilización de materiales, culto a las imágenes y copia de éstas, programas para ser transmitidos y formas afortunadas. ${ }^{10}$ Por medio de los testimonios notariales se pueden conocer detalles tales como procedencia de los materiales, calidades, usos, nombres y costos que redondean el panorama artístico y social en el cual estuvieron inmersas las obras.

${ }^{9}$ Aparte de su oficio, los artistas participaron en atras actividades remuneradas; hicieron vistas de ojos, reconocimientos, avalúos, etc.

10 Estos y otros problemas son estudiados desde hace varios años por Jorge Alberto Manrique, en su Seminario de Arte Colonial Mexicano, de la Facultad de Filosofía y Letras de la UNAM, División de Posgrado. En la sesión del 3 de noviembre de 1987, del Seminario de Escultura Novohispana. Esplendor Virreinal: Guatemala y México, celebrada en el Museo Nacional del Virreinato, el maestro Manrique presentó un trabajo titulado: "Problemas y enfoques en el estudio de la escultura novohispana", donde se enumeraton los principales problemas a los que se enfrenta el investigador. 
Ahora bien, cabe preguntarse: ¿Cómo lograba un trabajador de la madera la aceptación del público? ¿Cuáles fueron los diferentes públicos de las obras? ¿Qué papel jugaron dentro del mundo de las formas las propuestas de dos artistas como Manuel de Nava y Thomás Xuárez? ¿Qué determinaba que en la traza, montea, mapa o pitipé que se eligieran tales o cuales apoyos en vez de otros para elaborar sus proyectos? ¿Qué papel desempeñaron dentro de la sociedad novohispana los modelos afortunados, como el Nazareno de la iglesia del Hospital de la Pura y Limpia Concepción de la ciudad de México? ¿Cuál fue el papel dentro de la sociedad virreinal de un cacique artista que logró vincular su arte y formas de vida al mundo de las cofradías, los gremios y las ordenanzas?

Es de esperar que estas preguntas tengan pronto soluciones concretas; por ahora, sólo basta apuntar lo relevante de los anteriores puntos, así como su relación con los artistas y con los retablos.

Debe quedar advertido el lector que nuestras líneas tienen un doble propósito: primeramente, sumarse al homenaje que el Instituto de Investigaciones Estéticas rinde hoy, al dedicar este número de la revista Anales, a la memoria de uno de los más ilustres investigadores del arte, don Diego Angulo fñiguez y, en segundo término, dar a conocer nuevas noticias sobre una familia de artistas nobles encabezada por el indígena Thomás Xuárez, con la finalidad de contribuir en algo al conocimiento de un taller de escultura y ensamblaje que tuvo a su cargo la decoración interior de los más importantes templos de la Nueva España; de aquellos que hablaron al mundo de su época de la Grandeza Americana.

Las primeras noticias sobre la obra de Thomás Xuárez y Salvador de Ocampo fueron dadas a conocer en el ya citado estudio de Heinrich Berlín del año 1948."

Este autor fue, en efecto, el primero que relacionó a Xuárez con otros artistas de la familia y propuso algunas fechas para situar la actividad artística de sus miembros. Más tarde, Efraín Castro Morales y Guillermo Tovar de Teresa dieron a conocer otras noticias que contribuyeron en mucho a obtener una visión más amplia de la producción artística familiar. ${ }^{12}$ $\mathrm{Y}$ Tovar de Teresa aclaró, por primera vez, que se trataba de indígenas caciques. $^{13}$

${ }^{11}$ Heinrich Berlín, op cit.

12.2 El primer autor que habló de una familia de artistas fue Heinrich Berlin.

${ }^{13}$ Tovar de Teresa, op. cit., p. 25. 
Lo que ha quedado ya claro es que se trata de una familia compuesta por varios artistas, que fueron: Thomás Xuárez, cabeza del taller, Salvador de Ocampo, Joseph Lázaro Xuárez e Ignacio Xuárez de Córdoba, este último nuevo maestro de dorador, que aparece mencionado en uno de los documentos que aquí se dan a conocer y, por último, Simón de Ocampo, hijo del contratante del retablo mayor de Meztitlán. Por su parte Manuel Toussaint cita a un Mathías Xuárez, personaje del que no se tiene mayor información y que por la coincidencia de nombre y profesión este autor lo consideró posible pariente. Sin embargo, las fechas en las que aparece activo son muy tempranas para poderlo relacionar, por ahora, con el taller. ${ }^{14}$

Esta familia noble, de la que se ignora su genealogía, lugar de procedencia y otros datos esenciales, aparece activa por lo menos desde $1672-\mathrm{fe}$ cha en que Thomás Xuárez, a decir de George Warthon James, trabajó posiblemente junto con Alonso de Xeréz en la construcción del retablo mayor de la capilla de San Pedro de la catedral de México - hasta 1743, año en que, según Guillermo Tovar de Teresa, Simón de Ocampo trabajó en dos retablos de la iglesia franciscana de Tlanepantla. ${ }^{15}$

Conviene citar a continuación algunos de los encargos hechos en la ciudad de México, en los que con seguridad participó la familia, con objeto de ilustrar la importancia de esta clase de encargos y encargantes: parte del retablo mayor y sillería coral de la iglesia de San Agustín; retablo mayor de la iglesia Profesa; dos colaterales para uno de los claustros del convento grande de San Francisco; retablo de la Virgen de los Dolores de la Iglesia de San Pedro y San Pablo, entre otros magníficos ejemplos. El taller tuvo también importantes encargos en provincia; entre éstos destacan: la Santa Cruz de Querétaro (ver Documento No. 1), la iglesia de los Santos Reyes de Meztitlản y Xonacatepec (Documento No. 2).

Respecto a los encargantes con los que el taller de los Xuárez-Ocampo contrató, hay que resaltar que fueron figuras de enorme relevancia en la época; basta para ello citar dos casos: don Diego de Malpartida Zenteno y don Juan de Caballero y Ocio, cimeros ejemplos del patronazgo artístico noviohispano. ${ }^{16}$

Todo lo anterior pone en evidencia la importancia económica y artística alcanzada por esta familia. Desafortunadamente no se cuenta, hasta el mo-

14 Toussaint, op. cit., p. 112

15 Tovar de Teresa, op. cit., p. 26.

${ }^{16}$ Cfr. Gustavo Curiel, "Capilla de San Miguel" en Catedral de México, Patrimonio Artístico y cultural, México, Secretaría del Desarrollo Urbano y Ecología y Fomento Cultural Banamex, 1986, p. 203. 
mento, con ninguna noticia que refiera la actividad de Thomás Xuárez anterior a la fecha en que, según supone George Warthon James, pudo haber participado en la fabricación del retablo de la capilla de San Pedro, ni tampoco datos que aclaren por completo las fechas de nacimiento y muerte de los artistas.

Conviene ahora preguntarse: ¿Qué otras obras hizo Xuárez antes de conseguir un contrato con el Cabildo catedralicio? ¿Con quién se formó? ¿Fue su padre también artista de profesión y con él aprendió el oficio? ¿Hizo su padre retablos de filiación manierista? ¿Fue puesto en un taller como aprendiz? Estas y otras preguntas esperan ser contestadas pronto con apoyo documental.

Para volver a la importancia del taller, se mencionan a continuación algunos nombres de artistas ligados a este obrador de retablos: Alonso de Xeréz, Nicolás Rodríguez Xuárez, Juan Correa, Juan de Rojas, Andrés de Roa, Gregorio Godoy, Manuel de Vergara, Mathías de los Ángeles, Joaquín Rodríguez Rendón, Francisco Rodríguez de Santiago, Manuel de Nava, Joseph Gaona y Sarmiento y Francisco Sánchez. ${ }^{7}$

Si bien se sabe que los indígenas nobles -artistas o no- terminada la conquista gozaron de prebendas y privilegios, es poco lo que se conoce acerca de la posición social alcanzada por este grupo a lo largo de la Colonia. Sobre este punto resulta obligado mencionar el texto de Rubén Romero Galván; ${ }^{18}$ que, al igual que el libro Juan Gersón, tlacuilo de Tecamachalco, ${ }^{19}$ ampliaron el panorama que se tenía. Lo que sí se puede suponer es que Thomás Xuárez debió de haber gozado de una posición bastante desahogada. Esto queda de manifiesto en el hecho de que poseyó "dos pares de casas", las cuales solía dar en hipoteca al concertar las obras. No se sabe a ciencia cierta si su patrimonio lo pudo obtener gracias a la serie de encargos que contrató a lo largo de su vida o como producto de herencias o legados; sin embargo, lo que no se puede negar es que las obras en las que participó fueron importantes.

Conviene ver a continuación lo asentado en el Concierto de Obligación de obra (Documento No. 1), que aqui se publica:

${ }_{17}$ Los artistas que se citan trabajaron de alguna manera con el taller. Es posible que algunos de ellos sean los propios trabajadores del obrador de los Xuárez-Ocampo.

${ }_{18}$ Cfr. Rubén Romero Galván, "La familia noble indígena y la conservación de un poder disminuido". Ponencia en el III Simposio de Historia de las Mentalidades en su sesión del 5 de noviembre de 1986. Véase también: Boletín del Instituto de Investigaciones His. tóricas, México, Instituto de Investigaciones Históricas, UNAM, 1987, No. 21, pp. 3-11.

19 Rosa Camelo, Jorge Gurría Lacroix y Constantino Reyes Valerio, Juan Gersón, ilacuilo de Tecamacbalco, México, Instituto Nacional de Antropología e Historia, 1964. 
El cual dicho corateral han de formar con las condiciones y calidades que abajo se expresarán, $y$ tiene concertado el hacerlo por precio de dos mil y setecientos pesos, que se le han de dar a los plazos que se expresarán en esta escriptura; hipotecando para seguridad de ellos, dicho maestro Thomás Xuárez, dos pares de casas que tiene en esta ciudad, nuevas ... ${ }^{20}$

Líneas más adelante, el mismo documento informa:

Y para mayor seguridad y entrega del dicho colateral, el dicho Thomás Xuárez hipoteca por especial y expresa hipoteca, sin que la Especial derogue a la General ni por el contrario, dos pares de casas nuevas que tiene y posee en esta dicha ciudad; las unas altas en el barrio de San Gregorio y la otra en el barrio de Tomatlán, entresolada; para no poderlas vender, trocar, cambiar, ni en manera alguna enajenar ...21

Es de lamentar que no se hayan localizado, si es que existen, testimonios notariales relativos a los objetos materiales que poseyeron estos artistas, como Cuentas de división y Partición de caudales y bienes, Inventarios o Testamentos. Estos tipos de documentación darían una idea clara del status alcanzado por esta familia de nobles indígenas y de los que tenían puertas adentro de sus casas.

Un punto de importancia es sin duda el que se refiere a la conducción de los retablos destinados al adorno de los templos de provincia. De ello da buena cuenta el Documento No. 1:

Item, es Condición que ha de ser obligación de dicho maestro que fenecido que aiga dicho corateral lo ha de encajonar por su cuenta, y sólo ha de ser por la del dicho don Juan Caballero el conducirlo hasta la dicha ciudad de Querétaro a su costa, enviando todo el avio necesario para ello; como asimismo ha de enviar tres bestias ensilladas y enfrenadas para que vayan los oficiales que llevare dicho maestro, de quien ha de ser obligación el poner dicho corateral en dicho colegio de dicha Compañía de Jesús, armarlo y ajustarlo en el dicho sitio, y que quede con toda perfección y permanencia y a satisfacción de dicho licenciado don Juan Caballero ...22

Aunque son muy pocos los retablos que se conservaron en los que participó el taller, y uno de ellos se conoce solamente a través de litografías, se intentará a continuación apuntar algunas consideraciones.

${ }^{20}$ A.N Joseph Diez de Hortuño. No. 200. Vol. 1343. Ciudad de México, 16 de mayo de 1969 , Fs. 47 r. -51 r.

21 Ibidem.

22 Ibidem. 
Las obras del taller Xuárez-Ocampo muestran una clara preferencia por reticular los espacios, esto como clara herencia de la forma en que los retablos renacentistas concibieron el espacio. Nótese, si no, el sentido estructural con que está compuesto el incompleto retablo de Jesús Nazareno de la iglesia franciscana de Tlalmanalco, Edo. de México. ${ }^{23}$ Lo mismo sucede con los retablos de San Agustín de la ciudad de México y el de los Santos Reyes de Meztitlán, en Hidalgo. Cabe precisar que en algunos de ellos predomina la escultura; sin embargo, hay algunos casos en que ésta se combina con ejemplos pictóricos, y en otros es posible observar una marcada predominancia de la pintura sobre la escultura. Este último caso se ejemplifica en el retablo de Jesús Nazareno de la iglesia franciscana de Tlalmanalco y en el de San Miguel de la catedral de México, ya desaparecido.

Existe en los retablos una reiterada utilización de motivos que parecen ser las constantes formales del taller: motilos o macizos de niños, tarjas, pilastras hermes y, por supuesto, columnas salomónicas.

Predominan al parecer los capiteles de orden corintio, aunque hay que recordar que también los hay compuestos, como en el caso del de la Santa Cruz de Querétaro (Documento No. 1). Se trata de retablos que concentran su movilidad estructural en los apoyos; las columnas salomónicas se retuercen en sentido ascencional, unas veces desde el gálibo mismo y otras desde el primer tercio del fuste, imprimiendo a las obras con esta solución un marcado dinamismo ascencional, clásico del barroco. A lo anterior hay que añadir que uno de los retablos se pliega a manera de biombo, en tanto que el de Tlalmanalco, por ejemplo, no lo hace. Las esculturas, aunque plenamente barrocas, son comedidas en cuanto al movimiento. Hay cierta similitud formal entre las obras escultóricas realizadas por Manuel Nava y las de este taller, $v$. gr. la movilidad de los paños y la forma de marcar la cintura.

La calidad de los estofados y encarnaciones, según se puede observar en algunas esculturas y relieves, es espléndida, Véase en relación con esto la talla del Jesús Nazareno de Tlalmanalco, copia del que se veneraba en Ia iglesia del hospital de la Pura y Limpia Concepción de la ciudad de México que, si bien no ha sido limpiada, da buena cuenta del alto oficio alcanzado en el policromado y la terminación final.

${ }^{23}$ Acerca de este retablo se recomienda consultar: Gustayo Curiel, Tlalmanalco, bistoria e iconología del conjunto conventual, México, Instituto de Investigaciones Estéticas, 1988; en este trabajo se publica en el Apéndice Documental el texto que refiere la comisión de obra. Y también, Elisa Vargas Lugo, "Comentatios acerca de los documentos relacionados con la construcción de retablos" en Juan Correa. Su vida y su obra. Cuerpo de Documentos, cit. 
Asimismo, conviene precisar que existen similitudes formales y estructurales entre el perdido retablo de la Santa Cruz de Qurétaro, (Documento No. 1) y el que hace de mayor en la capilla de San Miguel de la catedral de México; este último retablo fue atribuido por Efrain Castro Morales al taller de Manuel de Nava. ${ }^{24}$ Por último, hay que señalar que ayudó mucho en la reconstrucción imaginaria del desaparecido de la Santa Cruz el mencionado retablo de la Metropolitana.

Relación de noticias sobre el taller de indigenas nobles

1665. Posible fecha de nacimiento de Salvador Ocampo según interpretación de Heinrich Berlín. ${ }^{25}$

1672. George Warthon James señaló la posibilidad de que Thomás Xuárez trabajara en compañía de Alonso de Xerez en la fabricación del retablo de San Pedro de la capilla de la misma advocación de la Metropolitana, con base en un documento que no pasó del Archivo de Notarías." ${ }^{26}$ Como se puede comprobar líneas abajo, estos dos artistas trabajaron en colaboración. El retablo, sin duda, presenta motivos formales y soluciones de las que participa el taller, por 10 que será necesario realizar estudios técnicos y recabar mayor información documental con la finalidad de ver si se puede o no atribuir al taller de Xuárez. Don Diego Angulo Îniguez se refirió a esta espléndida obra de la manera siguiente:

"A esta misma época ... de comienzos del último cuarto del siglo corresponde una interesante serie de retablos de la capital que se distinguen también por su decoración rica y menuda y por el empleo comedido de la columna salomónica, es decir, que presenta, en cierto grado, una etapa análoga a la de Bernardo Simón de Pineda o Barahona en Sevilla. Probablemente uno de los ejemplos más típicos es el de la capilla de San Pedro de la catedral ... en el que el ensamblador emplea columnas normales, aunque totalmente revestidas de ornamentación en el primer cuerpo, y las salomónicas en el segundo. Estas, según modelo frecuente en Sevilla, son cilíndricas

24 "Manuel de Nava, un escultor y ensamblador mexicano de los siglos XVII y XVIII" en Nuevo Museo Mexicano, México, s.e, 1985, Vol. 1, pp. 31-69.

25 Berlín, op, cit, p. 423.

26 Jorge Warthon James, "Un documento acerca del retablo de San Pedro de la catedral de México" en Boletín de Monumentos Históricos, México, Dirección de Monumentos Históricos, INAH, 1980. No. 4, pp. 17.22. 
en su tercio inferior. En el último cuerpo, en que se engloba la ventana, se reemplaza la columna por una especie de hermes o estípide de tardío estilo renacentista. En algunos golpes de decoración que enriquecen el conjunto, la influencia de roleos de los yeseros poblanos es bastante manifiesta.".27

1675. Aclara Efraín Castro Morales que el 26 de enero de este año se contrató la fabricación de un colateral para la capilla de San Miguel de la catedral. ${ }^{28}$ Alonso de Xerez y. Thomás Xuárez se concertaron con el licenciado Juan Torres Calderón para hacer un retablo que debería tener: "... de alto con zoclo y todo quince varas y de ancho once varas y tres cuartas, según de la forma y manera que se demuestra en el dibujo, modelo y montea que está fecho y dibujado en dos pliegos de marca mayor, pegado uno con otro". ${ }^{29}$ Este retablo se perdió en el incendio que sufrió la capilla el año $1711 .^{30}$

1678. Concierto de obligación de obra para la fabricación de un colateral dedicado a la Virgen de los Dolores para la iglesia de San Pedro y San Pablo de la ciudad de México. Celebraron el contrato Thomás Xuárez y Alonso de Xerez con el padre Joseph Vidal de la Compañía de Jesús. De la ejecución de las pinturas se encargaría el pintor mulato Juan Correa. ${ }^{31}$

1678. Concierto de obra para la ejecución del retablo mayor de la iglesia de Xocotitlán. En este documento aparecen mencionados otra vez los mismos artistas que trabajaron en el de la iglesia del Colegio Máximo de San Pedro y San Pablo.

1678. A decir de Silvia Bravo Sandoval, en esta fecha Thomás Xuárez y Mathías de los Ángeles contrataron con el religioso Jerónimo de Figueroa, padre prepósito de la Casa Profesa, la hechura de un monumento que tuvo de costo mil setecientos pesos de oro común. Los fiadores fueron Antonio García, Diego de Lara y Joseph [Lázaro] Xuárez. ${ }^{33}$

${ }^{27}$ Diego Angulo fñiguez, Historia del arte hispanoamericano, tomo II, Barcelona, Salvat Editores, $1945 \cdot 1950$, pp. 886-868.

${ }^{28}$ Castro Morales, "Manuel de Nava ...", cit., p. 55.

${ }^{29}$ A. N. Baltasar Morante. No. 379. Ciudad de México 26 de marzo de 1675.

${ }^{30}$ Manuel Toussaint, La Catedral de México y el Sagrario Metropolitano, su tesoro, su arte, México, Porrúa, 1973, pp. 151-152.

"1 Elisa Vargas Lugo, Gustavo Curiel, Juan Correa. Su vida y su obra. Cuerpo de Documentos, cit.

32 Ibidem.

${ }^{33}$ Silvia Bravo Sandoval, Notarios, México, Instituto de Investigaciones Estéticas, UNAM, 1985 (Catálogos de Documentos de Arte en el Archivo General de Notarías, México, No. 7). Juan Díaz de Rivera. p. 3, Ficha 015. 
1678. Heinrich Berlín indica: "As early as 1678 Thomás Xuárez must have enjoyed a solid reputation, or the fathers of the Society of Jesus would not have negotiated with him about making them a rich retable for the high altar of their church in Mexico City, La Profesa". ${ }^{34}$

1685. Tomás Xuárez contrató en este año "... un retablo para la Cofra" día de Ntra. Sra. del Tránsito que se ha de colocar en una ermita que se halla en los términos de la jurisdicción del pueblo de Tlalmaco". 35

1686. José Luis López Reyes señala que en esta fecha se llevó a cabo la ". . compra de un retablo al maestro ensamblador Thomás Xuárez, el cual fue colocado en el altar mayor de la Tercera Orden de San Agustín de esta ciudad. Se asienta [en el documento] ... que el hermano mayor Francisco de Montemayor y Prado donó una nueva imagen en el marfil de Nuestra Señora de Tránsito". 36

1688. El 20 de noviembre de este año pasó ante Miguel Leonardo de Sevilla, escribano 637, una Escritura de aprendiz en la que se obliga don Diego de Soto Osorio, receptor de la Real Audiencia de México, como padre legítimo de Juan de Soto, menor de "veinte años" a poner como aprendiz con Thomás Xuárez, maestro de ensamblador, a su hijo por espacio de cuatro años. El artista se comprometió a darle en cada un año: un vestido de paño diezciochesco, calzón, ropilla y capote o su valor en reales. Cfr. A.N. Miguel Leonardo de Sevila. No. 637. Vol. 4405. Fs. 89r.-89v.

1692. Concierto de obra para la ejecución de un retablo dorado de la advocación del Señor San Pedro para la iglesia franciscana de Tula. Thomás Xuárez aparece mencionado como maestro de ensamblador y Juan Correa como maestro de pintor. Estos artistas concertaron con fray Matheo de Arce, ministro de la jurisdicción de Tula. ${ }^{37}$

1693. Según informa Guillermo Tovar de Teresa, en este año Thomás Xuárez contrató la hechura "... del colateral mayor de la parroquia de Tlaxcala; en dicho documento aparece Salvador de Ocampo, su hijo, como fiador. Se menciona que el lugar central lo ocuparía la tilma Guadalupana, que lleva un marco de nácar, es decir, un mařco enconchado. El retablo, enorme, debió de ser muy suntuoso, pues

34 Heinrich Berlín, op cit, pp. 421-422.

${ }^{35}$ Guillermo Tovar de Teresa, México Barroco, México, SAHOP, 1981. p. 329.

${ }^{36}$ José Luis López Reyes, Ramo: Templos y Conventos, Segunda Parte, México, Instituto de Investigaciones Estéticas, UNAM (Catálogos de Documentos de Arte en el Archivo General de la Nación), México, 1985, p. 14, Ficha 091.

${ }^{7}$ Elisa Vargas Lugo, Gustavo Curiel, Juan Correa. Su vida y su obra. Cuerpo de Documentos, cit. 
se mencionan además de las columnas revestidas, ángeles 'volados' a los lados de la imagen". 38

1694. Thomás Xuárez contrata en esta fecha la fabricación del retablo de Jesús Nazareno de la iglesia franciscana de San Luis Obispo de Tlalmanalco; aparece mencionado como maestro de ensamblador y escultor. La obra fue concertada con Nicolás de Restra, mayordomo de la cofradía de Jesús de Nazareno, don Pedro García, rector, y don Francisco de la Cruz y Juan Roldán, diputados de la misma. Las pinturas fueron realizadas por Juan Correa. En la actualidad se conservan únicamente el sotabanco y el primer registro de este retablo." Elisa Vargas Lugo se ha ocupado de él en su artículo: "Comentarios acerca de los documentos relacionados con la construcción de retablos".40

1695. En esta fecha Thomás Xuárez concursó en la fabricación de la sillería coral de la catedral de México.43

1696. Contrato para el retablo mayor de la iglesia agustina de los Santos Reyes de Meztitlán. Celebraron el contrato Salvador de Ocampo y Nicolás Rodríguez Xuárez con el gobernador y alcaldes del mencionado pueblo. Aparecen como fiadores Joseph de Gaona y Sarmiento, maestro de batihoja, y Francisco Sánchez, maestro de dorador. Tuvo un precio de 6,800 pesos. ${ }^{42}$

1696. Contrato de Obligación de obra para la fabricación de un colateral de la Virgen de Guadalupe. Celebran el contrato, por una parte, el licenciado Juan Caballero y Ocio, presbítero domiciliario del arzobispo de México, vecino de la ciudad de Querétaro, comisario de los tribunales del Santo Oficio de la Inquisición y de la Santa Cruzada, dedicado a la cría de ganados mayores y menores $\mathrm{y}$, por la otra, el maestro de ensamblador y entallador Thomás Xuárez e Ig. nacio Xuárez de Córdoba, maestro de dorador y estofador, estos principales y caciques. Se ignora en qué fecha se destruyó el retablo. ${ }^{43}$

1697. El 13 de junio de 1697, Thomás Xuárez presentó su examen como maestro del gremio. En el mismo día fue examinado Andrés de Roa. $^{44}$

${ }^{38}$ Guillermo Tovar de Teresa, México Barroco, p. 329.

${ }^{39}$ Gustavo Curiel, Tlalmanalco . . Cfr. Apéndice Documental.

40 Elisa Vargas Lugo, "Comentarios ... en op. cit.

${ }^{41}$ Manuel Toussaint, Arte colonial.... cit, p. 111.

42 Heinrich Berlín, op. cit., pp. 512-514.

43 A. N. Joseph Díez de Hortuño. No. 200. Vol. 1343. Ciudad de México, 16 de mayo de 1696.

44 Heinrich Berlín, op cit., p. 421. 
1697. El 21 de enero de 1697 se obligó Thomás Xuárez, como principal, junto con sus hijos Salvador de Ocampo y Joseph Lázaro Xuárez, a realizar "tres cuerpos que faltan" para el perdido retablo mayor de San Agustín de México. ${ }^{45}$ El dorado fue contratado en 1698 por Simón y Nicolás de Espinosa. 46

1698. Sagún dato de Heinrich Berlín se sabe que en esta fecha Thomás Xuárez contrató la hechura de un retablo para la iglesia de Santa María Magdalena Quatlayauhcan. La obra tuvo un costo de 1200 pesos. ${ }^{47}$

1698.. Salvador de Ocampo presenta el examen de maestro del gremio. ${ }^{48}$

1699. José Luis López Reyes asienta lo siguiente: "México, Cd. Revisión de cuentas de la tercera orden de san Agustín, correspondientes al periodo comprendido entre el 4 de noviembre de 1696 al 27 de septiembre de 1699 , durante el cual se efectuaron varias obras en la capilla, sacristía, celdas, escalera y patio de portería del convento. En la f. 48 v. se menciona que Salvador de Ocampo puso los altares y el artesonado en blanco y que el hermano Joseph López [sic], maestreó, trabajó y dio los colores para pintar el artesón." ${ }^{39}$

1701. En esta fecha se asentó una Escritura de aprendiz en el protocolo de Diego Díaz de Rivera. "Gregorio de la Cruz, indio, de edad 14 años entra al servicio y por aprendiz de ensamblador con el maestro de dicho oficio Salvador de Ocampo, por tiempo de cinco años". 50

1701. Contrato con Fray Gaspar Ramos para realizar la sillería del coro de la iglesia de San Agustín de México. Se obligaron: Thomás Xuárez como principal, junto con Andrés de Roa y Francisco Sánchez, maestros de ensambladores todos. El documento dice a la letra: Salvador de Ocampo ... se obliga de hacer, labrar y acabar dicha sillería poniendo en ella además de su trabajo personal y maestría los oficiales más primorosos que de este oficio hubiese, herramientas, colas clavazón para dicha sillería, herraje y demás cosas necesarias, menos las maderas que éstas se le han de dar ....51

1701. Efraín Castro Morales, al destacar la alta calidad de los retablos que se dispusieron en los claustros novohispanos, informa que Thomás

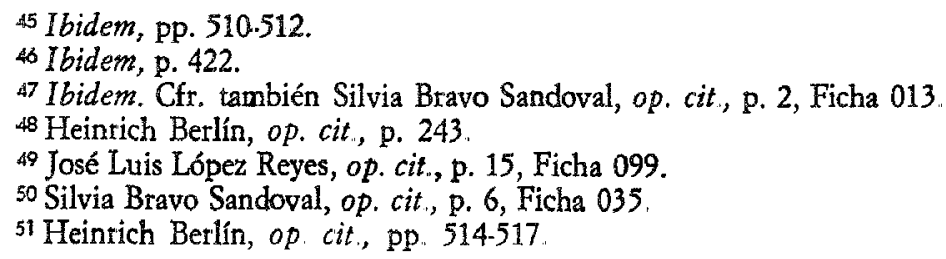


Xuárez hizo dos para San Francisco de México, uno dedicado a la Purísima Concepción de María y el otro a San Miguel Arcángel. Estas obras deberían tener dos cuerpos y remate. Su costo fue de 1300 pesos. ${ }^{52}$

1705. Es también este autor el que informa: "... se reunieron en la casa del maestro Juan Rojas, el 10 de marzo de 1705, ante el escribano y testigos, Francisco Rodríguez de Santiago, Manuel de Nava, Andrés de Roa, Gregorio Godoy y Salvador de Ocampo, los seis maestros arquitecto-talladores, para que por escritura pública constara como, después de haberse separado del gremio de los carpinteros y obtenido sus ordenanzas, que fueron leidas, declararon que aunque en ellas quedó asentado que se había elegido la iglesia del Espíritu Santo para colocar un retablo dedicado a San José 'su abogado y patrón', no se había efectuado, y viendo la dilación de su fábrica se reunieron para pedir a la abadesa y religiosas del nuevo convento de Santa Teresa, al doctor Miguel González de Valdeosera, su capellán mayor, y al licenciado Juan de Dios Ocampo, presbítero, su mayordomo administrador, les diese un lugar en su iglesia para poner retablo, el cual les fue asignado en el crucero, al lado de la Epístola ..."

1710. El 3 de julio de este año se asentó en el protocolo del escribano Miguel Leonardo de Sevilla una carta de pago por 1000 pesos en favor del maestro de ensamblador Salvador de Ocampo por haber "hecho y acabado con toda perfección" un colateral de San Agustín para la iglesia de Nuestra Señora del Tránsito del pueblo de Xonacatepec. Se ignora en qué fecha se destruyó el retablo. ${ }^{54}$

1710. En este año, el 15 de octubre, Juan de Rojas, Thomás Xuárez y Salvador de Ocampo llevaron a cabo una vista de ojos del retablo mayor de la iglesia de San Lorenzo de esta ciudad que para ese entonces estaba en malas condiciones. ${ }^{55}$

1712. Guillermo Tovar de Teresa asienta que en esta fecha Thomås Xuårez contrató "... un retablo consagrado a 'Cristo Nuestro Señor', en la iglesia del convento de Santo Domingo de la ciudad de Méxi$\mathrm{co}^{30} .{ }^{56}$

52 Castro Morales, "Manuel de Nava ...", pp. 33.34.

${ }^{53}$ Ibidem, p. 42.

5i A. N. Miguel Leonardo de Sevilla. No. 635. Ciudad de México, 3 de julio de 1710.

Fs. 18 \%. 19 r.

55 Efraín Castro Morales, "Manuel de Nava...", p. 48.

so Tovar de Teresa, México Barroco, p. 330. 
1714. Berlín cita que Thomás Xuárez participó en la fabricación del retablo de Santa Francisca Romana de la iglesia de la Merced de México. Pedro Arieta fue el fiador. ${ }^{57}$

1720. En esta fecha, según Manuel Toussaint, Thomás Xuárez llevó a cabo un aprecio de escultura. ${ }^{58}$

1732. Probable fecha de muerte de Salvador de Ocampo, según Heinrich Berlín, con base en una declaración de ese mismo año de su hijo Simón de Ocampo, quien: "... presents a receipt for the completion of the altarpiece of St. Francis in the church of La Regina, wich his father had begun, and had left unfinished death overtook him". ${ }^{99}$

1732. Según informa el mismo autor, en esta fecha se nombra a Simón de Ocampo como maestro. ${ }^{60}$

1743. Informa Guillermo Tovar de Teresa que en esta fecha Simón de Ocampo trabajaba en dos retablos para la iglesia franciscana de Tlanepantla siguiendo la planta que "... delineó Don Isidoro Vicente de Balbás ... que se halla en poder de Don Simón de Ocampo". 61

1746. En esta fecha, según noticia de José Luis López Reyes, se asienta en una razón que "Simón de Ocampo es el autor del retablo mayor, [de la iglesia de Tacuba] concluído y corregido por el maestro Joseph García Castañeda"..2

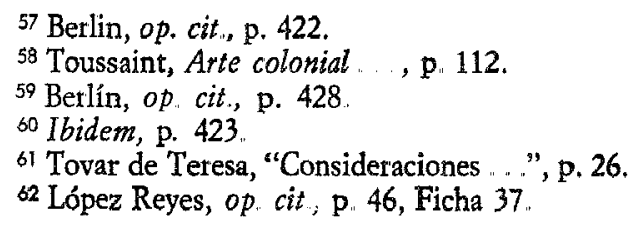


DOI: http://dx.doi.org/10.22201/iie.18703062e.1988.59.1410

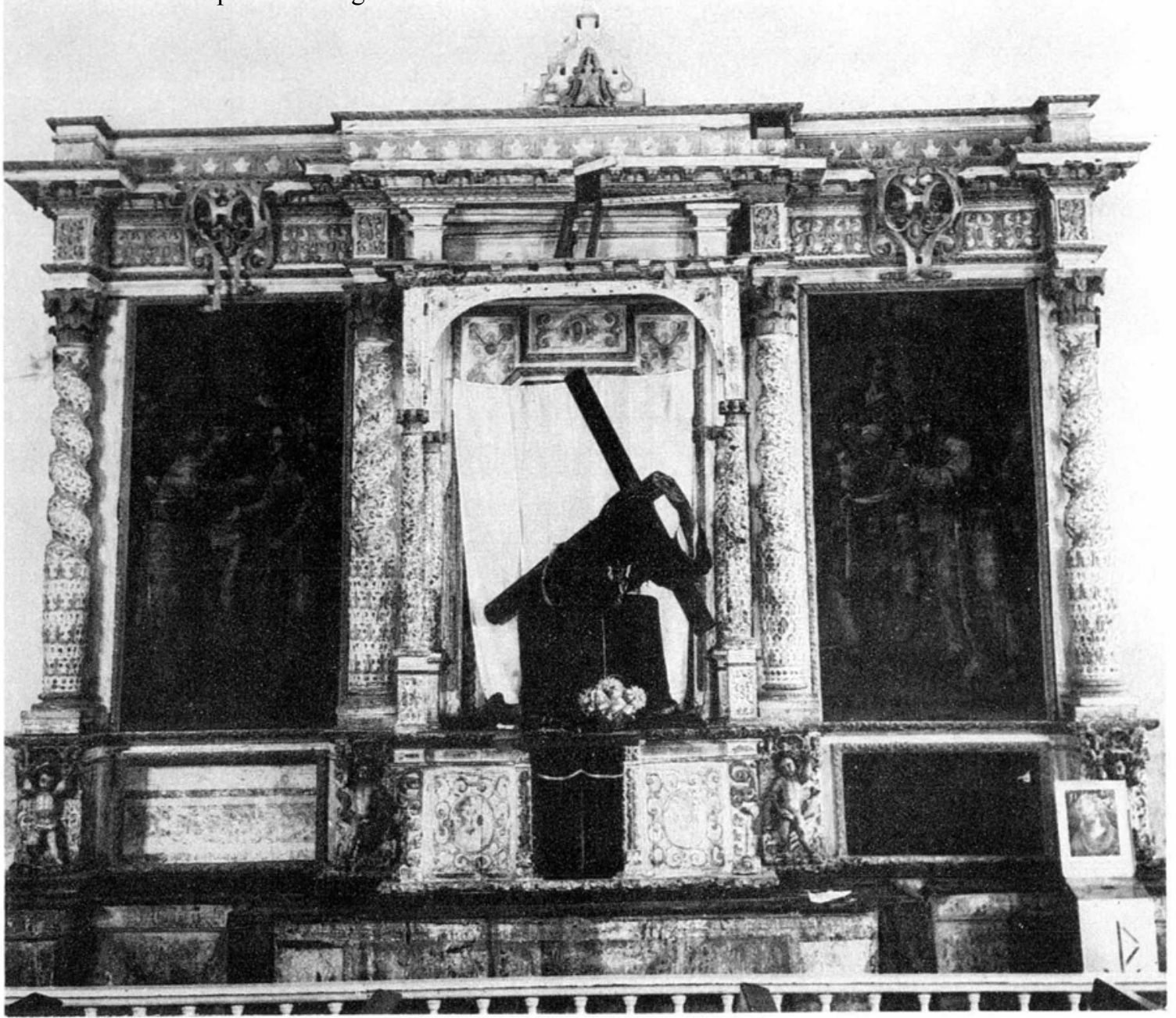

Figura 1. Thomas Xuárez. Retablo de la Pasión. Escultura según modelo. Iglesia franciscana de San Luis Obispo de Tlalmanalco. Foto: G.V. y R.R. 


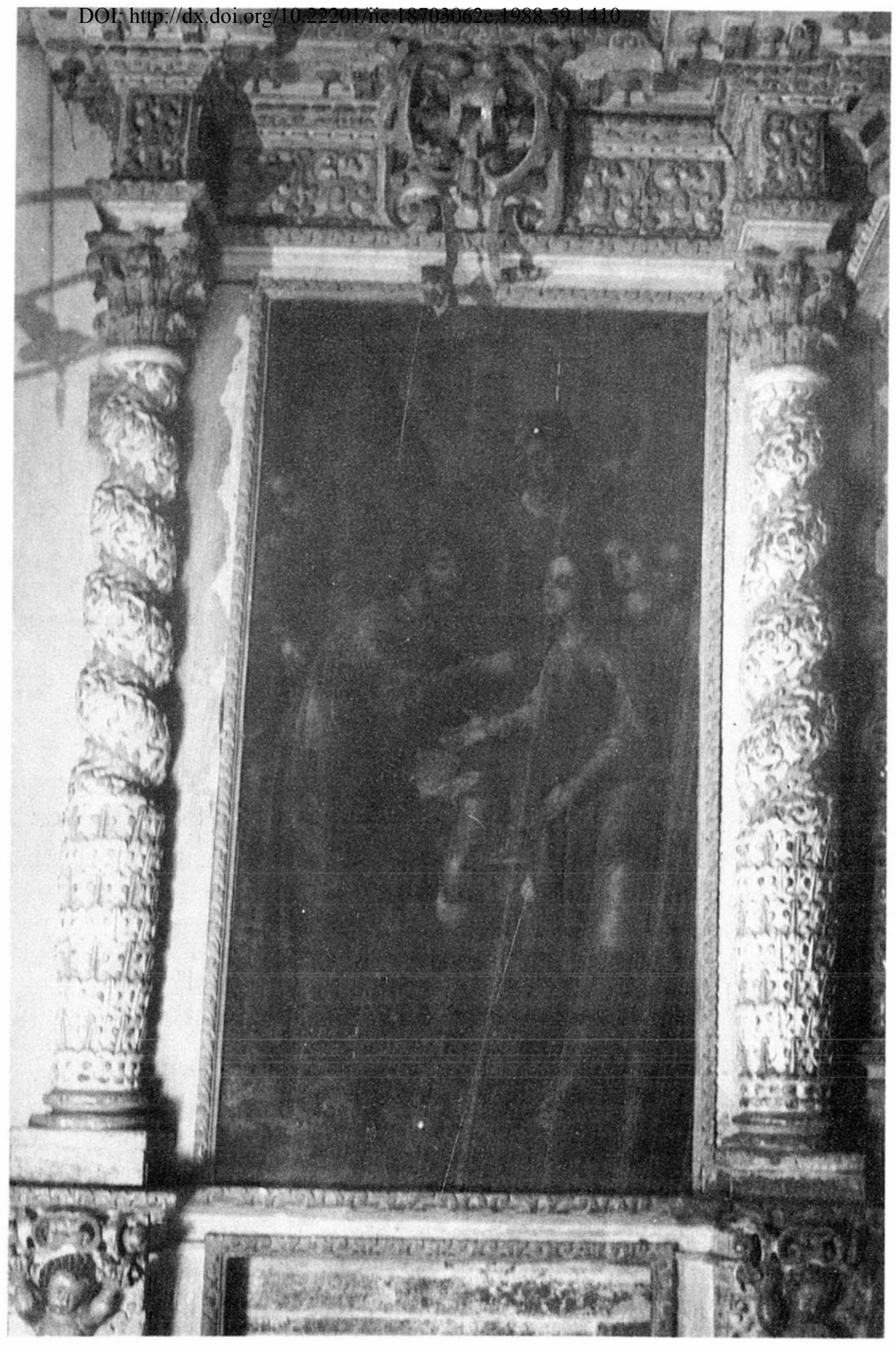

Figura 2. Detalle del retablo anterior. Entrecalle izquierda. Oleo de Juạn Correa. Foto: G.V. y R.R. 


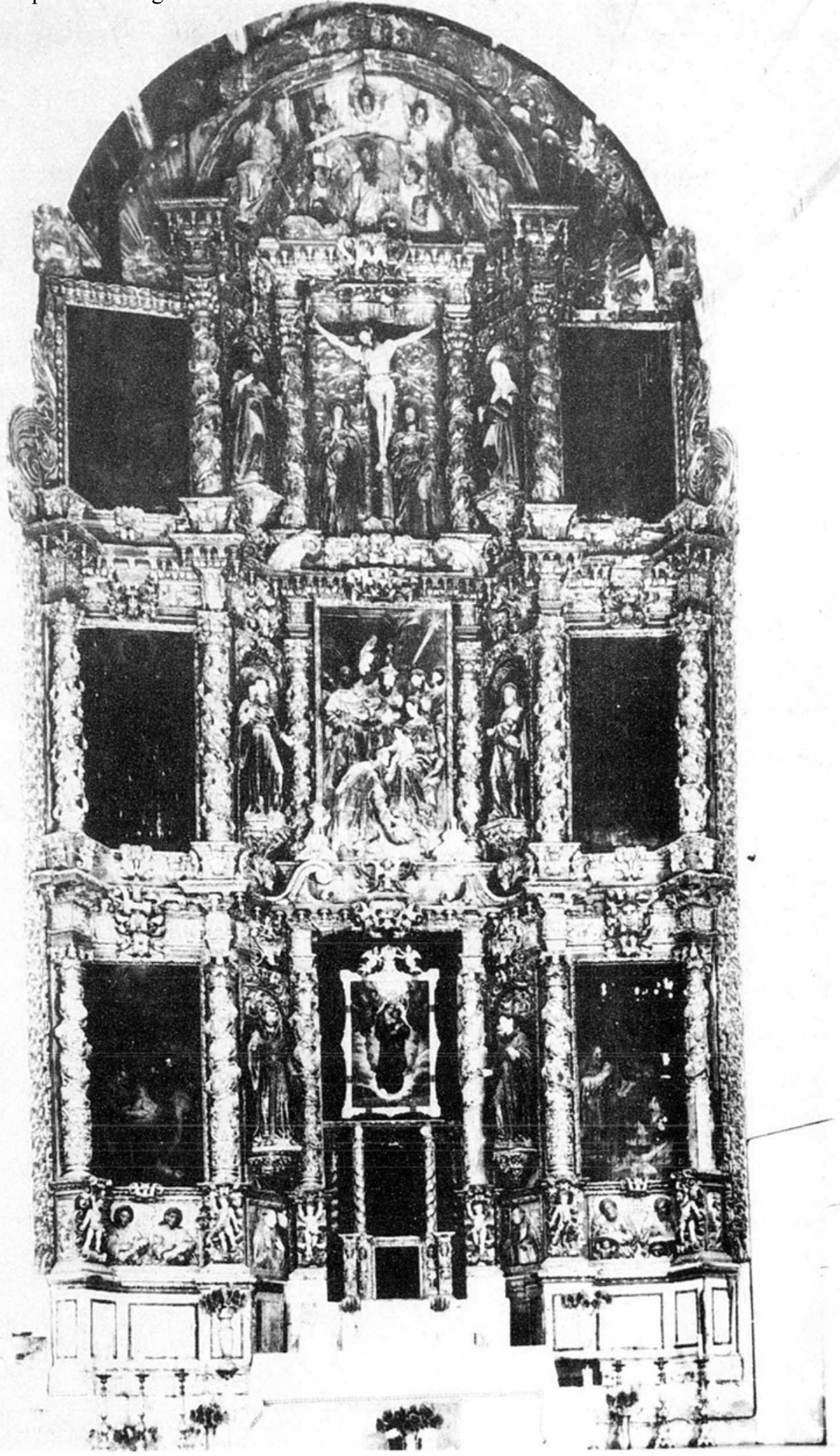

Figura 3. Salvador de Ocampo. Retablo mayor de la iglesia de los Santos Reyes de Meztitlán, Hidalgo. Foto: IIE. 
DOI: http://dx.doi.org/10.22201/iie.18703062e.1988.59.1410

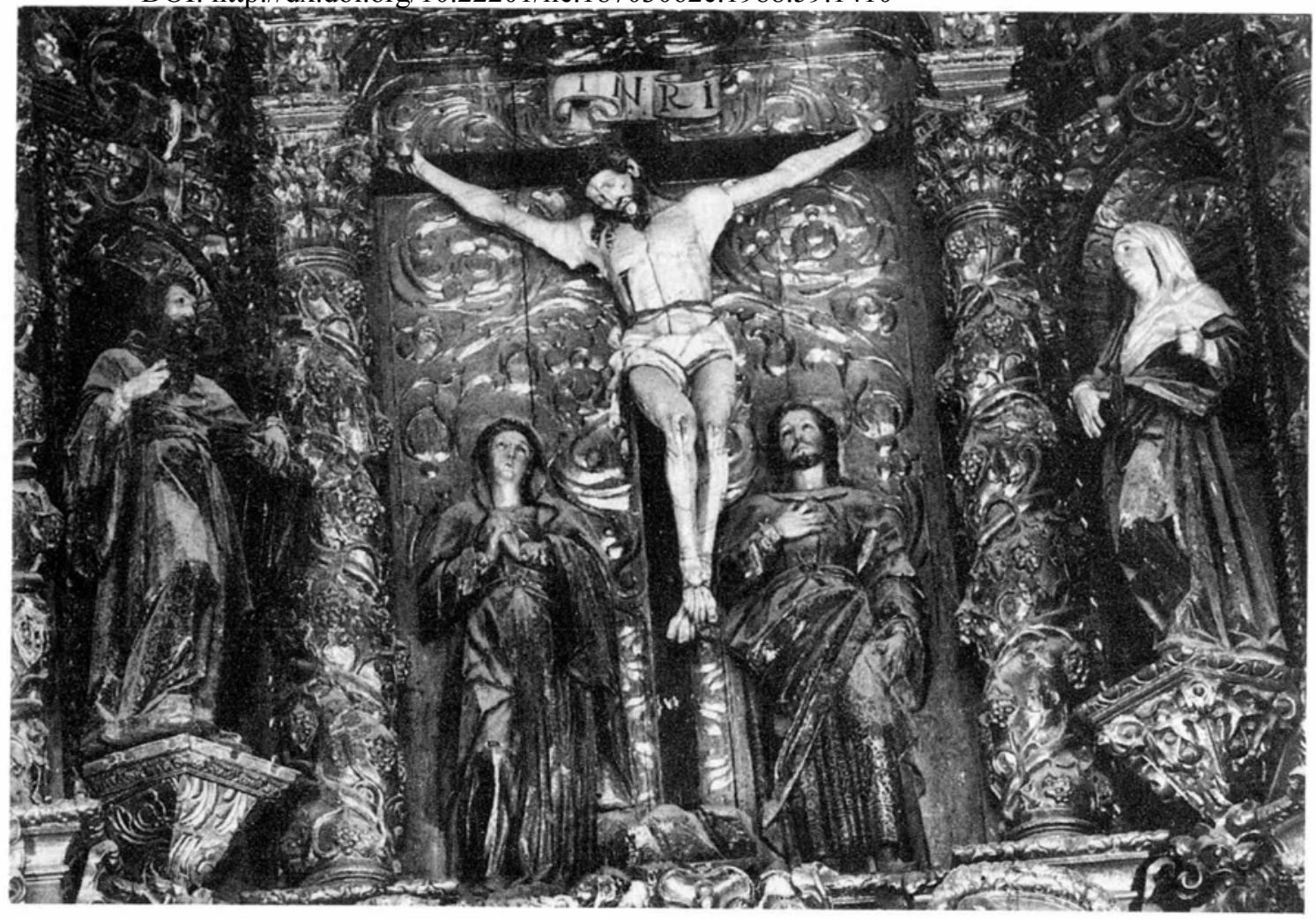

Figura 4. Detalle del retablo anterior. Foto: IIE. 


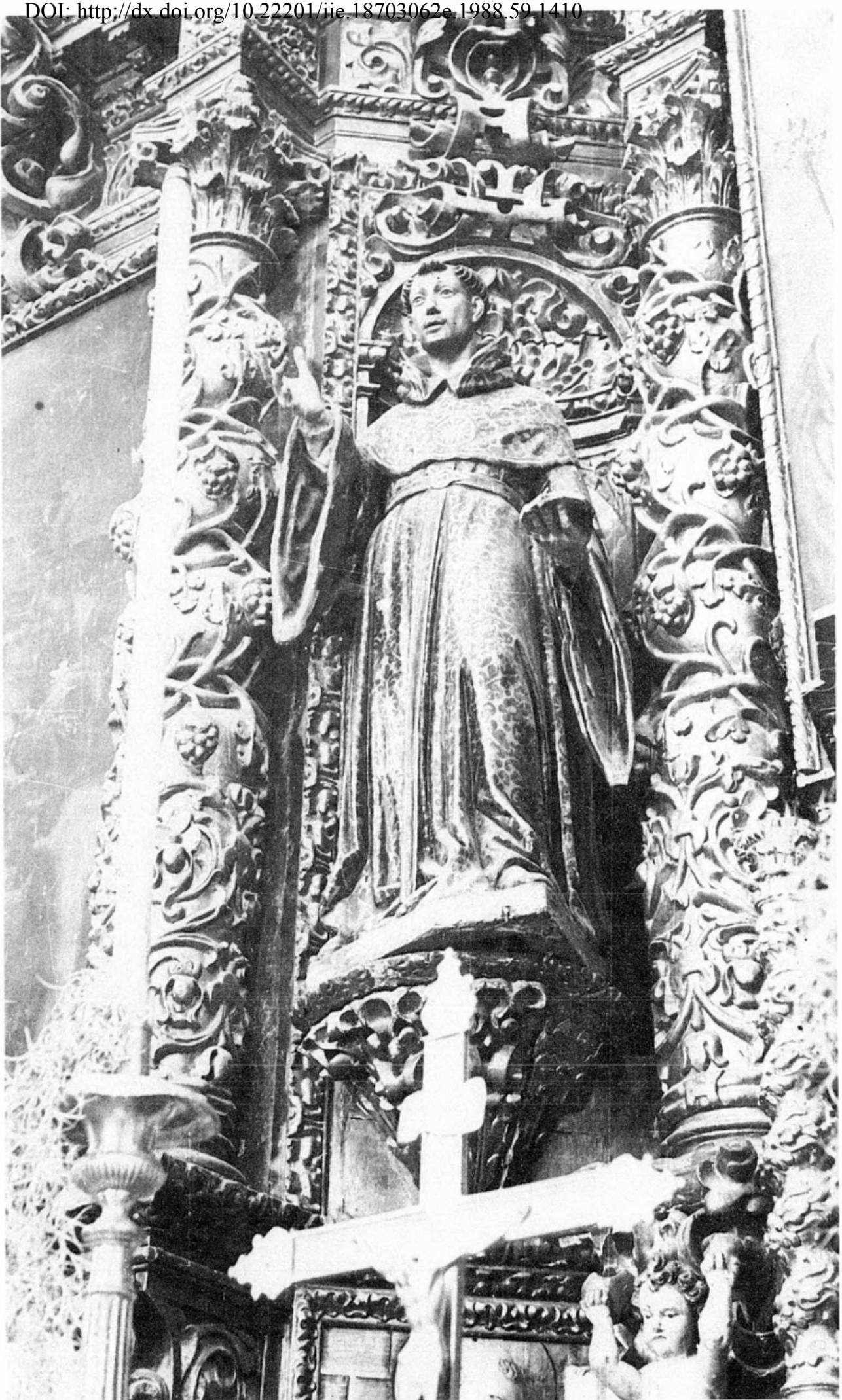

Figura 5. Detalle del retablo anterior. Foto IIE. 
DOI: http://dx.doi.org/10.22201/iie.18703062e.1988.59.1410

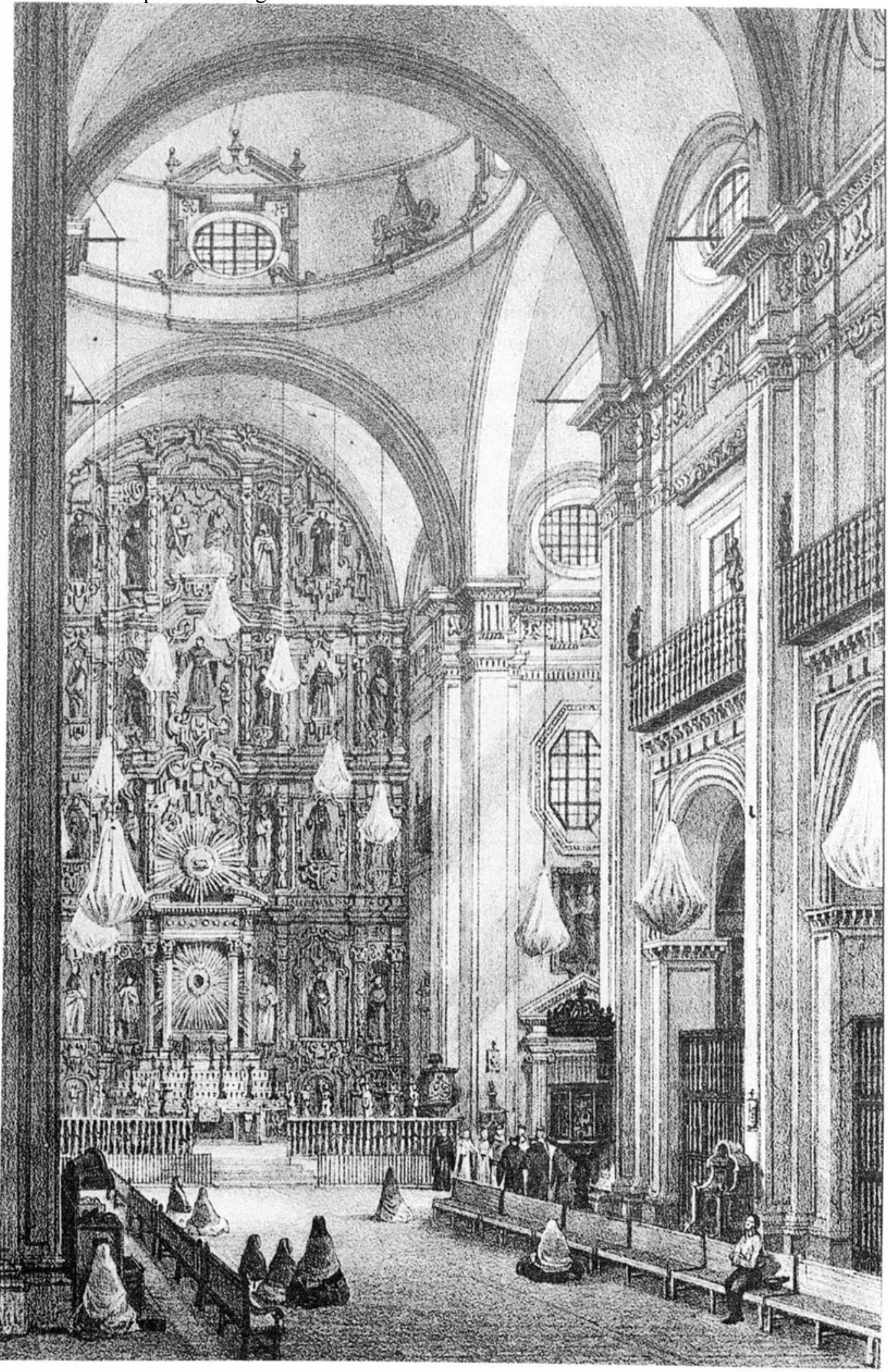

Figura 6. Interior de la iglesia de San Agustín de México. Litografía. Foto INAH. 
DOI: http://dx.doi.org/10.22201/iie.18703062e.1988.59.1410

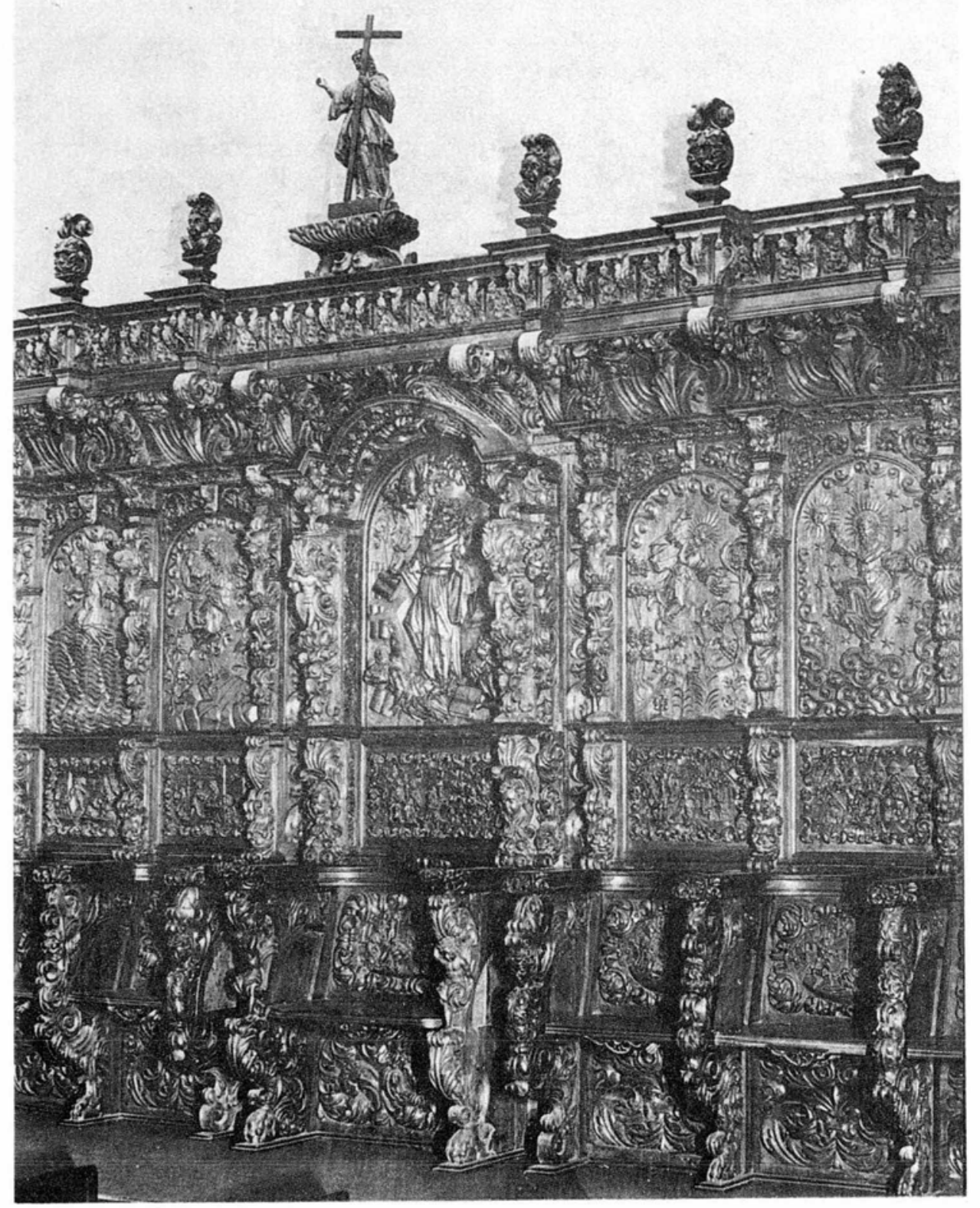

Figura 7. Sillería del coro de San Agustín de México. Actualmente en el "Generalito". Foto: IIE. 


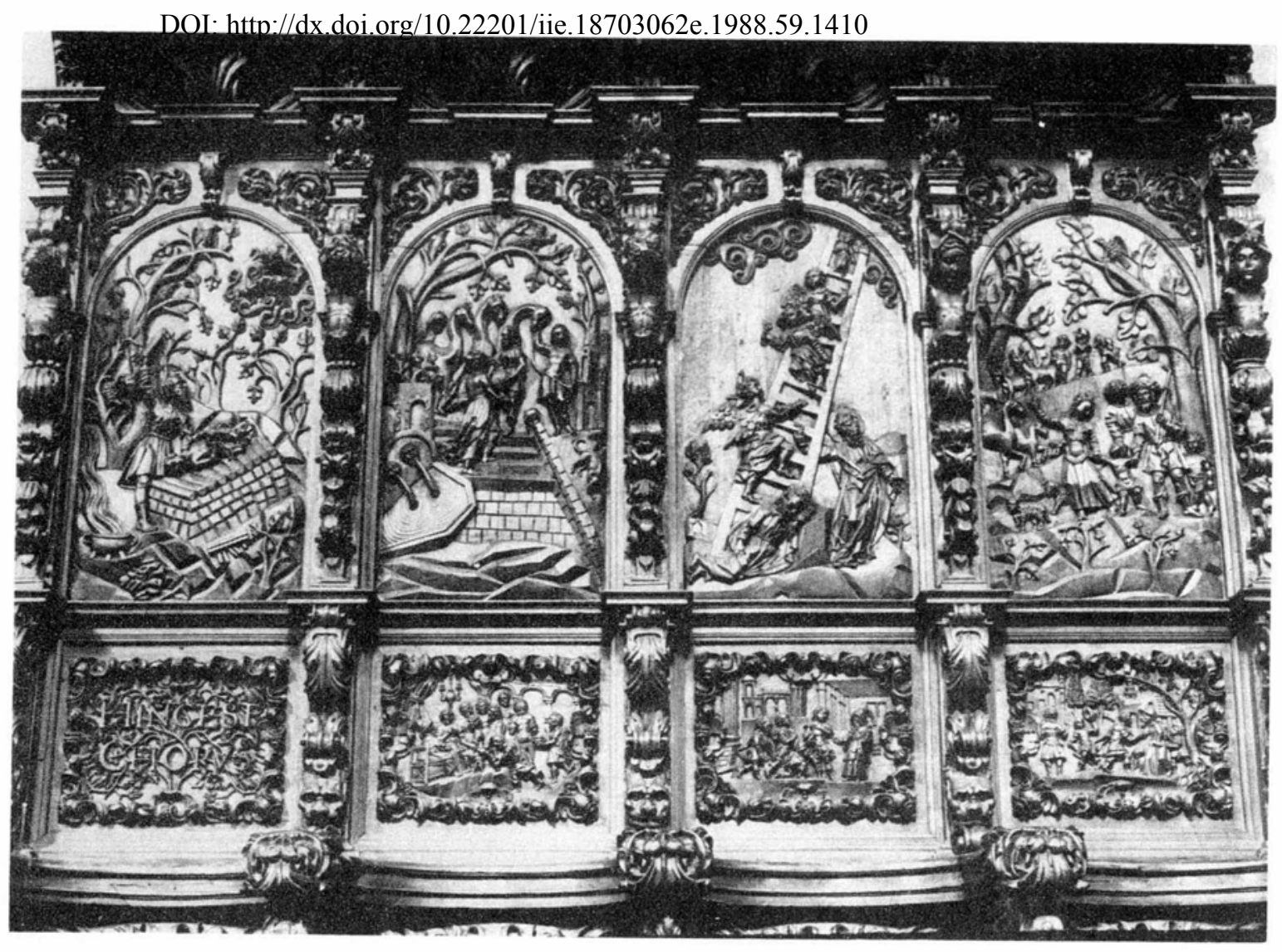

Figura 8. Detalle de la anterior. Foto: P. C. 


\section{DOCUMENTO No. 1}

A.N. Joseph Díez de Hortuño. No. 200. Vol. 1343. Ciudad de México. 16 de mayo de 1696. Fs. 47 r.-51 r.

[Concierto de obligación de obra para la fabricación de un colateral de la Virgen de Guadalupe. Celebran el contrato, por una parte, el licenciado Juan Caballero y Ocio, presbítero domiciliario del arzobispo de México, vecino de la ciudad de Querétaro, comisario de los tribunales del Santo Oficio de la Inquisición y de la Santa Cruzada, dedicado a la cría de ganados mayores y menores $\mathrm{y}$, por la otra, el maestro de ensamblador y entallador Thomás Xuárez e Ignacio Xuárez de Córdoba, maestro de dorador y estofador, éstos últimos indios principales y caciques. Se ignora en qué fecha se destruyó el retablo.]

\section{[f. 47 r.] [Crismón]}

\section{[Al margen izquierdo:Escriptura de]}

[Al margen izquierdo: contrato de un colateral. Fecho para en la parte del dicho licenciado don Juan Cavallero, hoy 25 de mayo de 1696, en papel del sello segundo, doy fe. Rúbrica del escribano.]

\section{[f. 47 r.]}

En la ciudad de México, en diez días del mes de mayo de mil seiscientos y noventa y seis años, ante mi el escribano y testigos parecieron de la una parte, el licenciado don Juan Cavallero y Ocio, presbítero domiciliario de este arzobispado, vecino de la ciudad de Santiago de Querétaro, comisario de los tribunales del Santo Oficio de la Inquisición y de [la Santa] Cruzada de este reino, y criador de ganados mayores y menores en la dicha jurisdicción; y de la otra Thomás Xuárez y Ignacio Xuárez de Córdoba, principales y caciques. El uno maestro de ensamblador y entallador y el otro maestro de dorador y estofador, vecinos de esta ciudad, a quienes doy fe conozco. Y dijeron que por cuanto tienen tratado y concertado con el dicho licenciado don Juan Cavallero el hacerle un corateral para dicha ciudad de Querétaro, que se ha de colocar en el colegio de la Compañía de Jesús de dicha ciudad, segün el mapa y traza que tienen formada y entregada a dicho licenciado para su perfección, que queda rubricada de mí el presente escribano, para su cumplimiento de que se ha de obligar dicho Thomás Xuárez, maestro de ensamblador y entallador como principal y dicho Ignacio Xuárez de Córdoba, maestro de dorador y estofador, como su fiador.

El cual dicho colateral han de formar con las Condiciones y calidades que abajo se expresarán. $Y$ tienen concertado el hacerlo por precio de dos mil y setecientos pesos, que se les han de dar a los plazos que se expresarán en esta escriptura; hipotecando para seguridad de ellos, dicho maestro Thomás Xuárez dos pares de casas que tiene en esta ciudad, nuevas, cuyo entrego han de hacer en el tiempo de diez meses, dejándolo perfectamente arma- 
do, los cuales han de empezar a correr y contarse de la fecha de esta escriptura en adelante, en lo cual han convenido. Y reduciéndolo a efecto en la mejor vía y forma que por derecho lugar haya, [ ] e informados de sus derechos, el dicho Thomás Xuárez, como principal y el dicho Ignacio Xuárez de Córdoba, como su fiador princial [f. $48 \mathrm{r}$.] y llano pagador, $\mathrm{y}$ sin que contra dicho principal preceda [sic], ni se haga diligencia, ni excursión de fuero ni de derecho, cuyo beneficio expresamente renuncia[n]. Y juntos, de mancomún, a voz de uno y cada uno de los dichos, por sí y por el todo insolidum, con renunciación de las leyes de la mancomunidad, división, excursión y fianza, como en ellas se contiene y declara, otorgan que se obligan de formar el dicho corateral según la traza y mapa que tienen entregadas al dicho licenciado don Juan Cavallero, que queda como va dicho rubricada de mí el presente escribano; y [a] ponerlo en toda forma en el dicho colegio de la Compañía de Jesús de dicha ciudad de Querétaro, con las calidades y Condiciones que tienen pactadas, y son como se sigue:

Primeramente, es Condición que han de formar dicho colateral según dicha traza y mapa y columnas que en él se contienen; el cual ha de ser en el dicho colegio de la Compañia de Jesús de dicha ciudad. Y ponerlo en él en la capiIla mayor, en el lado de la Epístola, que hace crucero, llenando todo el sitio, de su ancho y de su alto, según se demuestra en dicha traza y mapa; que estån dos trazas en una, y se ejecuta la traza que hace el lado de la Epístola que tiene ocho columnas en el primer cuerpo; y se obre en él según arte de dicho mapa para su cumplimiento e individuación.

Item, es Condición que ha de comenzar dicho colateral con un zoclo según arte, con sus puertas a los dos lados; la una ha de ser movediza para la entrada de la sacristía; y la otra acompañará para la igualdad del repartimiento de los dos lados.

Item, es Condición que sobre dicho zoclo se ha de formar un banco para el retablo con ocho macizos, en que se han de formar ocho Niños en ellos, y guarnecidos con todos sus ornamentos de moldura [tachado], plintos y cuarto boceles, y laboreados segín dicho arte; con puerta de sagrario y dos Santos a los lados de él, como lo demutestra el dicho mapa.

\section{[f. $48 \mathrm{v}$.}

Item, es Condición que se ha de formar en dicho corateral un nicho en la calle de enmedio del primero cuerpo con ocho columnas y dos entrecalles de nichos, en que se han de acomodar dos Santos, de talla, que han de ser el Glorioso Archangel San Miguel y el Señor San Juan Baptistas con su Cor" dero; que éstos han de ser de obligación de los maestros el formarlos; respecto de estar hecho y formado ya el del Señor San Francisco Xavier que está en el dicho colegio de Querétaro, para dicho primero cuerpo; y lo que contienen los dos, sus ornamentos de ocho pilastras con sus guardapolvos a los dos extremos que cierren el sitio de su ancho, con toda la perfección que se requiere y sea necesaria, según dicho arte y mapa. 
Item, es Condición que las dichas cornijas para coronar todo dicho primero cuerpo con dichas ocho columnas y macizos de él y de todo el dicho corateral, según dicho arte, han de ser con toda la perfección que se requiere y va expresado en la Condición antecedente. $Y$ se ha de componer de orden carintio con todos sus ornamentos que se requieren según lo tienen repartido en dicho mapa.

Item, es Condición que para el segundo cuerpo ha de comenzar con un sota. banco sobre las cornijas del dicho primero cuerpo. En la calle de enmedio un nicho para que se coloque la Virgen Santisima de Guadalupe, de talla, según el original, que es de obligación de dicho maestro el hacerla de nuevo, estofada y dorada y encarnada, en su nicho, según dicho mapa. $Y$ asimesmo dos nichos a los lados para que se coloquen en ellos el Glorioso Patriarca Señor San loseph, en el uno, y en el otro Santa Teresa de lesús, asimismo de talla de madera, dorada y estofada y encarnada, los cuales dichos tres bultos [f. $49 \mathrm{r}$.] de talla han de ser, con toda perfección, según dicho mapa.

Item, en dicho segundo cuerpo han de formar ocho columnas con ocho pilastras con sus guardapolvos de extremo a extremo, que cierren todo el ancho, según dicha traza.

Item, es Condición que se ha de poner en dicho corateral una cornija que corone todo el primero cuerpo que corresponde a todas las ocho columnas, de orden compuesto, que hacen diez y seis columnas de primero y segundo cuerpo, según arte.

Item, es Condición que el remate de toda la dicha obra ha de comenzar sobre un sotabanco, según el primero cuerpo para que reciba dicho remate con la ventana en el medio, y dos cuerpecillos a los dos lados, con dos tableros de pinturas, que se han de pintar; en el lado del Evangelio, San Francisco de Sales, y en el de la Epístola San Nicolás Obispo, con todos sus ornamentos y arte, que cierre el arco y la ventana con su capialsado en la ventana, con toda perfección, según dicha traza.

Item, es Condición que según dicha traza que tiene hecha para dicha obra, dicho maestro, que ha de hacer con dos macizos más en el banco de dos Niños de escultura, dos en el remate del sotabanco y dos en la cornija y dos en la bichas que la reciben, que es la última, y dos en el nicho de San Francisco Xavier que se hacen por las tallas que se augmentan para mayor adorno de dicho corateral [perdido] piezas de escultura, ansí de talla como estofadas y encarnadas, a satisfacción de mraestros de dicho arte.

Item, es Condición que todas las maderas de dicho corateral han de ser de ayacahuites y cedros, a toda satisfacción, para lo cual se han de nombrar maestros de dicho arte, asi de dorado como de estofado para que reconozcan dicho corateral luego que esté acabado, para que vean si está conforme a arte, y faltando cualquier cosa, según dicho mapa y traza; o teniendo algún 
defecto, lo ha de hacer y enmendar dicho maestro hasta que quede con toda perfección, sin que por dicha razón pueda llevar ni pedir más cantidad de pesos que en la que está [f. 50 r.] ajustada. $Y$ en defecto de no hacerlo dicho maestro o su fiador ha de poder dicho licenciado don Juan Cavallero darle a acabar el dicho corateral a los maestros de dicho arte que el pareciere y por la cantidad de pesos que gastare y pagare por él o lo que faltare, la ha de satisfacer dicho maestro y su fiador, diferida su liquidación en el juramento simple del dicho don Juan Cavallero, como asimismo no dándolo al tiempo que va expresado y por lo que montare le pueda ejecutar con más las costas, daños y menoscabo que se le recrecieren.

Item, es Condición que ha de ser obligación de dicho maestro, que fenecido que aiga dicho corateral lo ha encajonar por su cuenta y sólo ha de ser por la del dicho don Juan Cavallero el conducirlo hasta dicha ciudad de Queré. taro a su costa, enviándo todo el avío necesario para ello; como asimesmo ha de enviar tres bestias ensilladas y enfrenadas para que vayan los oficiales que llevare dicho maestro, de quien ha de ser obligación el poner dicho corateral en dicho colegio de dicha Companía de Jesús, armarlo y ajustarlo en el dicho sitio, y que quede con toda perfección y permanencia y a satisfacción de dicho licenciado don Juan Cavallero; sin que por razón de irle a poner se le dé a dicho maestro ni a sus oficiales cosa alguna, por que todo entre en el ajuste de los dichos dos mil y setecientos pesos de su valor.

Item, es Condición que dicho corateral ha de dar acabado dicho maestro dentro de diez meses, que han de empezar a correr y contarse desde hoy día de la fecha de ésta escriptura en adelante; y por precio de los dichos dos mil y setecientos pesos. Que le ha de dar los un mil de ellos luego, en contado, como con efecto lo tiene hecho; de que se dá por entregado a su voluntad; sobre que renuncia [f. 50 r.] leyes de la entrega, prueba del recibo y demás del caso para efecto de principiar dicha obra y de dicha fecha de ésta escriptura en tres meses se la han de dar otros un mil pesos; y dentro de nueve meses, de dicha fecha, se le han de dar los setecientos pesos restantes, cumplidamente a dichos dos mil y setecientos pesos en que está ajustado el valor del dicho corateral.

Con todas las cuales dichas Condiciones otorgan que celebran dicha escriptura. Y se obligan [el] dicho Thomás Xuárez a dar fenecido el dicho corateral dentro del término que va asignado en ella, según y en la forma de dicho mapa y traza que queda como ha dicho, rubricado del presente escribano. $Y$ darlo encajonado y bien dispuesto por su cuenta para que se condusga por la del dicho licenciado don Juan Cavallero a dicha ciudad de Querétaro, en donde se obliga dicho maestro a ir a ponerlo, llevando los oficiales que fueren necesarios para ello hasta dejarlo ajustado; y por defecto de no hacerlo o por cualquier cosa que falte, se obliga a darle cumplida. mente el dicho Ignacio Xuárez de Córdoba, como tal su fiador que se constituye, y que cumplirá con todas las calidades de dicha escriptura, sin que falte cosa alguna de ellas; lo cual ejecutará bien llanamente, sin contienda 
de juicio, con las costas y salarios de su cobranza [a] razón de dos pesos de oro de minas que gane en cada un dia la persona que a ella fuere de los que se ocupare en idas, estadas y vueltas, hasta que se consiga el entrego del dicho corateral y calidades de ésta escriptura. $Y$ el dicho licenciado don Juan Cavallero se obliga a dar y entregar al dicho Thomás Xuárez y a quien' su derecho representare los dichos un mil y setecientos pesos; los un mil de ellos de la fecha de esta escriptura en tres meses, y los setecientos restantes de dicha fecha en nueve. $Y$ para el cumplimiento de ésta escriptura, por lo que a cada uno toca [f. 50 v.] obligaron, el dicho licenciado don Juan Ca. vallero sus bienes, y los dichos Thomás Xuárez y Ignacio Xuárez [de] Córdoba sus personas y los suyos, habidos y por haber; y con ellos se sometieron, el dicho licenciado don Juan Cavallero a las que de sus catisas conforme a derecho puedan y deban conocer, y los dichos Thomás Xuárez y Ignacio Xuárez de Córdoba al fuero y jurisdicción de las justicias de su majestad, de cualesquier partes que sean, en especial de las de ésta dicha ciudad, su corte $y$, Audiencia Real que en ella reside, con renunciación de los suyos domicilio [s] y vecindad, ley si combenerit, las demás de su favor y defensa, con la general del Derecho, para que a lo dicho les compelan y apremien, por lo que a cada uno toca, como por sentencia pasada en autoridad de cosa juzgada.

$Y$ para mayor seguridad y entrego del dicho corateral, el dicho Thomás -Xuärez hipoteca por especial y expresa hipoteca, sin que la Especial Derogue a la General ni por el contrario dos pares de casas nuevas que tiene y posee en esta dicha ciudad; las unas altas en el barrio de San Gregorio y otra en el barrio de Tomatlán, entresolada; para no poderlas vender, trocar, cambiar, ni en manera alguna enajenar hasta tanto que tenga entregado el dicho corateral y dado cumplimiento a las Condiciones de esta dicha escriptura pena de que si lo contrario hiciera, sea en sí nulo $[y]$ de ningún valor, ni efecto y le pueda sacar de terceros y más poseedores. $Y$ asi la otorgaron y firmaron, [f. 51 r.] siendo testigos el capitán don Juan de Hoyo y Asoca [?] Cavallero, Esteban de Estrada y Juan Andrés de Olivian, presentes y vecinos de esta dicha ciudad. Testado, valiado.

Thoan Cavallero y Ocio [Rúbrica]
Thomás Xuárez [Rúbrica]

Ignacio Xuárez de Córdoba [Rúbrica]

Ante mí: Joseph Díez Hortuño

Escribano real y de provincia

[Rúbrica]

Derechos: 4 reales 


\section{DOCUMENTO No. 2}

A.N. Miguel Leonardo de Sevilla. No. 635. Ciudad de México. 3 de julio de 1710 . Fs. 18 v. -19 r.

[Carta de pago por 1000 pesos en favor del maestro de ensamblador Salvador de Ocampo por haber "hecho y acabado con toda perfección" un colateral de San Agustín para la iglesia de Nuestra Señora del Tránsito del pueblo de Xonacatepec. Se ignora en qué fecha se destruyó el retablo].

\section{[f. $18 \mathrm{v}$.}

[Al margen izquierdo: Carta de pago de 1,000 pesos. Fecho.] En la ciudad de México a tres días del mes de julio de mil setecientos y diez años, ante mí el escribano y testigos [pareció] Salvador de Ocampo, maestro de ensamblador, vecino desta dicha ciudad, aquien doy fe conozco; otorga haber recibido del capitán don Pedro de Sigura Urresolagaray, vecino desta dicha ciudad, como albacea testamentario de don Antonio de Arrigoreta, un mil pesos de oro común en reales, que le da y paga por haber hecho y acabado con toda perfección un corateral de San Agustín en la iglesia de Nuestra Señora del Tránsito que está en la villa de Xonacatepeque; que por Cláusula del testamento que otorgó el dicho capitán don Antonio de Arrigoreta dejó ordenado se hiciera, de cuya cantidad se dio por entregado a su voluntad. Sobre que renuncia las leyes del no entrego y su prueba, como en ellas se contiene, y otorga recibo y carta de pago en toda forma; y quedar, como queda dicho otorgante, integramente pagado y satisfecho con dicha cantidad, y no que [f. 19 r.] darle a deber por dicha obra otra ninguna cantidad. Y lo firmó, siendo testigos: don Joseph de la Torre, Joseph González de la Madrid y Bernardo García de la Bandera, vecinos de esta dicha ciudad. Entre renglones: San Agustín. Vale.

\section{Salvador de Ocampo [Rúbrica]}

Derechos: un peso
Ante mí: Miguel Leonardo de Sevilla, escribano real. [Rúbrica] 